\section{Nitrogen Form and Solution pH Effect on Organic Acid Content of Cranberry Roots and Shoots}

\author{
Deborah L. Allan', Bruce D. Cook ${ }^{2}$, and Carl J. Rosen ${ }^{1}$ \\ Department of Soil Science, University of Minnesota, St. Paul, MN 55108
}

Additional index words. Vaccinium macrocarpon

\begin{abstract}
The effect of $\mathrm{N}$ form and solution $\mathrm{pH}$ on the carboxylic and phenolic acid content of cranberry (Vaccinium macrocarpon Ait. cv. Searles) shoots and roots was determined in a greenhouse experiment. The predominant carboxylic acids measured were malate and citrate. Protocatechuic acid was the dominant phenolic acid detected. Total organic acid concentrations were unaffected by $\mathbf{N}$ form supplied. In shoots, higher total concentrations of organic acids were found at $\mathrm{pH} 4.5$ than at 6.5 in the shoot, but there was little $\mathrm{pH}$ effect in the roots.
\end{abstract}

A unique characteristic of many Ericaceous plants is their adaptation to ammonium-N nutrition and low soil-pH conditions. Previous work has shown that cranberries respond better to $\mathrm{NH}_{4}-\mathrm{N}$ than to $\mathrm{NO}_{3}-\mathrm{N}$ (Greidanus et al., 1972), although $\mathrm{NO}_{3}-\mathrm{N}$ has sometimes been beneficial (Dirr, 1974; Leschyson and Eaton, 1971). Our experiments showed that cranberry fresh weight accumulation and final dry weight were higher when plants were supplied with either $\mathrm{NH}_{4}-\mathrm{N}$ or $\mathrm{NH}_{4}-\mathrm{N} / \mathrm{NO}_{3}-\mathrm{N}$ than with $\mathrm{NO}_{3}-\mathrm{N}$ alone (Rosen et al., 1990).

Mechanisms for tolerance of $\mathrm{NH}_{4}-\mathrm{N}$ by Vaccinium spp. are not known, but may be related to a lower cation requirement or a greater ability to synthesize organic acids in the absence of $\mathrm{NO}_{3}-\mathrm{N}$ compared to nontolerant plants (Salsac et al., 1987). For most plants, shoot concentrations of carboxylic acids are higher with $\mathrm{NO}_{3}-\mathrm{N}$ nutrition, due to the requirement for charge balance for the cations accompanying nitrate uptake once the nitrate is reduced and assimilated (Haynes and Goh, 1978; Kirkby and Mengel, 1967; Marschner, 1986). In ammonium-fed plants, organic acids are typically at low levels due to amino acid formation (Haynes and Goh, 1978). Phenolic content of plants is also affected by $\mathrm{N}$ supply (Marschner, 1986).

The objectives of this research were to determine the effect of $\mathrm{N}$ form and $\mathrm{pH}$ on the organic acid constituents of cranberry roots and shoots. Because we saw differences in plant response to $\mathrm{N}$ form, we expected to see corresponding differences in carboxylic and phenolic acid production.

\footnotetext{
Received for publication 9 July 1993. Accepted for publication 26 Oct. 1993. Minnesota Agricultural Experiment Station Journal article no. 20,698, The cost of publishing this paper was defrayed in part by the payment of page charges. Under postal regulations, this paper therefore must be hereby marked advertisement solely to indicate this fact.

'Associate Professor,

${ }^{2}$ Research Fellow.
}

San Jose, Calif.) fitted with an HPX-87 column and guard column (Bio-Rad Laboratories, Richmond, Calif.). Analyses were performed using a $5 \%$ to $30 \%$ acetonitrile/ 0.008 $\mathrm{N} \mathrm{H}_{2} \mathrm{SO}_{4}$ gradient at $0.8 \mathrm{ml} \cdot \mathrm{min}^{-1}$ and $45 \mathrm{C}$ column temperature. Peaks were detected with an ultraviolet detector at $210 \mathrm{~nm}$ and identified by cochromatography with known standards. Succinic and shikimic acid standards coeluted with a retention time of $8.53 \mathrm{~min}$. Data were analyzed using PROC ANOVA (SAS Institute, 1985), and means were separated using Duncan's multiple range test at $P \leq 0.05$ where appropriate.

\section{Results}

Citric and malic acids were the dominant carboxylic acids in shoots and roots of cranberry plants. Protocatechuic acid was the dominant phenolic acid. Oxalic acid was not detected in shoot extracts. In shoot extracts, there were no significant differences in concentrations of organic acids for different $\mathrm{N}$ forms, but citric, t-aconitic, and fumaric acid concentrations were significantly higher under $\mathrm{pH}$ 4.5 than 6.5 (Table 1). Succinic and/or shikimic acid followed the same trend, with significantly higher concentrations at $\mathrm{pH} 4.5$ than 6.5 (data not shown). Results reported for blueberry indicate that this chromatographic peak is likely to be primarily composed of shikimic acid (Neuendorff and Patten, 1989), in which case shikimic acid would be a dominant phenolic acid. The concentration of t-aconitate was higher at $\mathrm{pH} 4.5$ than 6.5 for the $\mathrm{NO}_{3}$ and $\mathrm{NH}_{4}$ treatments (data not shown), but lower for the combined $\mathrm{N}$ treatment, resulting in a significant interaction.

In root extracts, only syringic and benzoic acids were at higher concentrations at $\mathrm{pH} 4.5$ than at 6.5, and these acids were present in very small amounts (Table 2). Nitrogen form affected fumaric, oxalic, protocatechuic, and vanillic acid concentrations, but there were no differences for the dominant acids. Only for syringic acid was there a significant treatment interaction, in which root concentrations were higher at $\mathrm{pH} 4.5$ than 6.5 for the $\mathrm{NO}_{3}-\mathrm{N}$ source, but lower for the combined and $\mathrm{NH}_{4}-\mathrm{N}$ source (data not shown).

The only difference among treatments in concentrations of total carboxylic acids, phenolic acids, or the combined organic acids was due to a $\mathrm{pH}$ effect in the shoots, primarily due to the increased concentration of citrate at $\mathrm{pH}$ 4.5 .

\section{Discussion}

Because N form affected 'Searles' cranberry growth (Rosen et al., 1990), we expected an effect of $\mathrm{N}$ source on the organic acid content. In typical $\mathrm{N}$ metabolism, organic acids accumulate in nitrate-fed plants to maintain charge balance due to excess cation uptake and subsequent reduction of $\mathrm{NO}_{3}$ (Haynes and Goh, 1978). In addition, there is often an increase in the $\mathrm{pH}$ of the nutrient solution due to excretion of hydroxide or bicarbonate. In our previous work, plant weight was depressed 


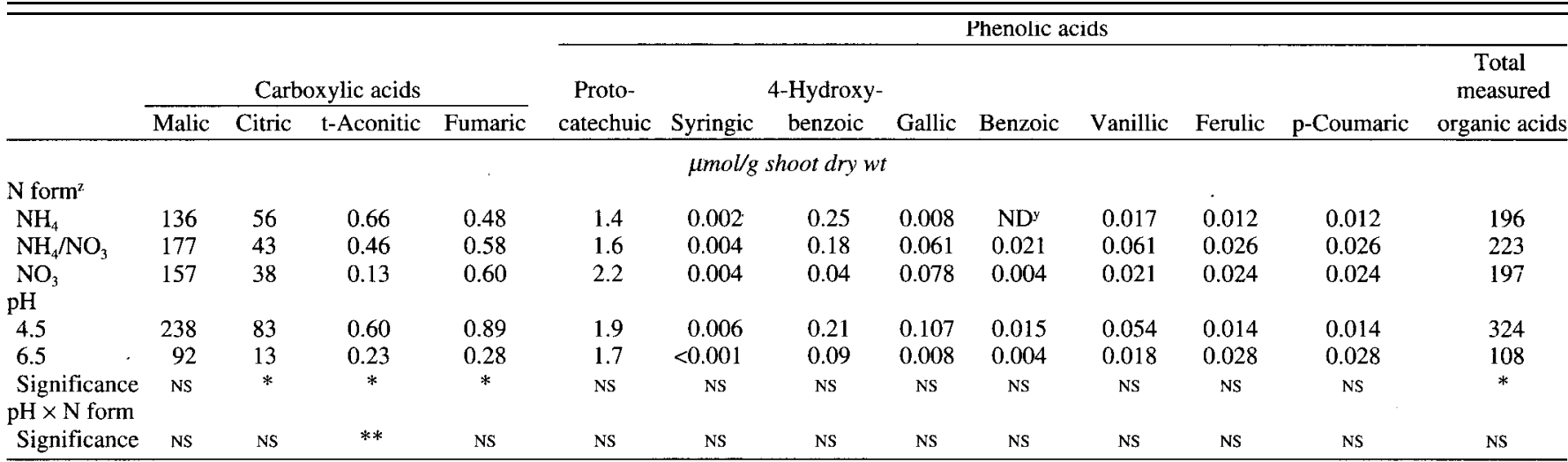

${ }^{2}$ Effects due to $\mathrm{N}$ form were nonsignificant for any organic acid.

${ }^{y} \mathrm{ND}=$ not detected.

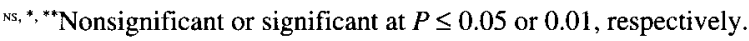

when $\mathrm{N}$ was supplied as $\mathrm{NO}_{3}$, and rates of uptake were 30 to 100 times lower than for $\mathrm{NH}_{4}-\mathrm{N}$ (Rosen et al., 1990). There was no change in the $\mathrm{pH}$ of the nutrient solution of the nitrate-fed cranberry plants, nor in the rate of cation uptake (milliequivalents $\mathrm{K}+\mathrm{Ca}+\mathrm{Mg}$ per gram dry weight was about equal among $\mathrm{N}$ treatments). As we concluded previously, there may have been minimal uptake of $\mathrm{NO}_{3}$, especially at $\mathrm{pH} 6.5$, so the plants did not respond with increased synthesis of organic acids.

Although plants that are not adapted to ammonium nutrition generally have a lower organic acid content (Haynes and Goh, 1978) and often display $\mathrm{Ca}$ and $\mathrm{Mg}$ deficiencies, it appears that cranberry, like many other $\mathrm{NH}_{4}$-adapted species, can fix $\mathrm{CO}_{2}$ into organic acids sufficiently to compensate for the uptake of excess cations, including $\quad \mathrm{NH}_{4}^{+}$, and to provide carbon skeletons for detoxification and a supply of amino acids and amides to shoots (Salsac et al., 1987; Woolhouse, 1966). In some cases, the demand for carbohydrate supply with $\mathrm{NH}_{4}-\mathrm{N}$ nutrition can be so high that there is little to invest in root growth, with subsequent decreases in root mass (Lewis et al., 1990). Restricted root growth in $\mathrm{NH}_{4}$-fed plants can be ascribed to the cumulative effect of increased respiration, greater allocation of $\mathrm{C}$ to nitrogenous compounds, and the increased export of $\mathrm{C}$ from root to shoot compared to that occurring in $\mathrm{NO}_{3}$-fed plants. In our previous experiments, root mass was lowest with the $\mathrm{NH}_{4}-\mathrm{N}$ form (Rosen et al., 1990), but cation uptake and organic acid content were maintained.

At low substrate $\mathrm{pH}$, the efficiency of the proton efflux pump at the plasma membrane decreases, and downhill transport of protons into the cytoplasm increases (Marschner, 1986). Electrochemical potentials of root cells can decrease from $-150 \mathrm{mV}$ at $\mathrm{pH} 6$ to -100 $\mathrm{mV}$ at $\mathrm{pH} 4$ (Dunlop and Bowling, 1978). The result is that cation uptake is generally inhibited at low $\mathrm{pH}$. Thus, one would predict lower organic acid concentrations because there is lower cation uptake and consequent requirement for charge balance.

In this experiment, we found significantly higher levels of some organic acids at low $\mathrm{pH}$ (4.5 vs. 6.5). Previous research demonstrated that shoot uptake of $\mathrm{K}, \mathrm{Ca}$, and $\mathrm{Mg}$ was about equivalent (Rosen et al., 1990), which indicates that cranberry plants are able to maintain their cation content even under low-pH conditions. If higher rates of dark $\mathrm{CO}_{2}$ fixation (as have been shown to occur in response to $\mathrm{NH}_{4}$ nutrition; Salsac et al., 1987) can occur at low $\mathrm{pH}$, cation uptake could be maintained despite lower cell electrochemical potentials. Perhaps higher organic acid content may provide a means to maintain negative cell potentials at low $\mathrm{pH}$.

Although cranberry growth was affected by N source (Rosen et al., 1990), the organic acid concentrations of shoots and roots did not change substantially. Apparently, $\mathrm{NO}_{3}$ uptake was not great enough to result in an accumulation of organic acids as is expected with $\mathrm{NO}_{3}$ nutrition. Higher organic acid concentrations, however, were observed at low $\mathrm{pH}$, possibly due to increased dark $\mathrm{CO}_{2}$ fixation to maintain negative cell potential and cation uptake.

\section{Literature Cited}

Dirr, M.A. 1974. Nitrogen form and growth and nitrate reductase activity of the cranberry. HortScience 9:347-348.

Dunlop, J. and D.J.F. Bowling. 1978. Uptake of phosphate by white clover. II. The effect of $\mathrm{pH}$ on the electrogenic phosphate pump. J. Expt. Bot. 29:1147-1153,

Greidanus, T., L.A. Peterson, L.E. Schrader, and M.N. Dana. 1972. Essentiality of ammonium for cranberry nutrition. J. Amer. Soc. Hort. Sci. 97:272-277.

Haynes, R.J. and K.M. Gob. 1978. Ammonium and nitrate nutrition of plants. Biol. Rev. 53:465510.

Kirkby, E.A. and K. Mengel. 1967. Ionic balance in different tissues of the tomato plant in relation to

Table 2. Solution $\mathrm{pH}$ and $\mathrm{N}$ form effects on concentrations of carboxylic and phenolic acids in cranberry root extracts

\begin{tabular}{|c|c|c|c|c|c|c|c|c|c|c|c|c|c|c|}
\hline & & & & & & \multicolumn{9}{|c|}{ Phenolic acids } \\
\hline & \multicolumn{5}{|c|}{ Carboxylic acids } & \multirow{2}{*}{$\begin{array}{c}\text { Proto- } \\
\text { catechuic }\end{array}$} & \multirow{2}{*}{ Syringic } & \multirow{2}{*}{$\begin{array}{l}\text { 4-Hydroxy- } \\
\text { benzoic }\end{array}$} & \multirow{2}{*}{ Gallic } & \multirow[b]{2}{*}{ Benzoic } & \multirow[b]{2}{*}{ Vanillic } & \multirow[b]{2}{*}{ Ferulic } & \multirow[b]{2}{*}{$\mathrm{p}$-Coumaric } & \multirow{2}{*}{$\begin{array}{c}\text { Total } \\
\text { measured } \\
\text { organic acids }\end{array}$} \\
\hline & Malic & Citric & t-Aconitic & Fumaric & Oxalic & & & & & & & & & \\
\hline \multicolumn{15}{|c|}{ umol/g shoot dry wt } \\
\hline $\mathrm{N}$ form & & & & & & & & & & & & & & \\
\hline $\mathrm{NH}_{4}$ & 36 & 63 & 0.33 & $0.10 b^{x}$ & $1.9 \mathrm{a}$ & $0.57 \mathrm{~b}$ & 0.19 & 0.16 & $N D b^{y}$ & 0.068 & $0.052 \mathrm{a}$ & ND & ND & 102 \\
\hline $\mathrm{NH}_{4} / \mathrm{NO}_{3}$ & 65 & 101 & 0.63 & $0.24 \mathrm{a}$ & $2.7 \mathrm{a}$ & $0.70 \mathrm{ab}$ & 0.26 & 0.02 & $\mathrm{ND} b$ & 0.091 & $0.042 \mathrm{ab}$ & ND & ND & 171 \\
\hline $\mathrm{NO}_{3}$ & 38 & 52 & 0.43 & $0.07 \mathrm{~b}$ & $\mathrm{ND} b$ & $1.21 \mathrm{a}$ & 0.19 & 0.02 & $0.034 \mathrm{a}$ & 0.024 & $0.020 \mathrm{~b}$ & 0.026 & 0.027 & 92 \\
\hline $\begin{array}{l}\text { Significance } \\
\mathrm{pH}\end{array}$ & e NS & NS & NS & $*$ & $* *$ & $*$ & NS & NS & $* *$ & NS & $*$ & NS & NS & NS \\
\hline 4.5 & 48 & 63 & 0.44 & 0.11 & 1.8 & 0.6 & 0.32 & 0.02 & 0.024 & 0.105 & 0.036 & ND & ND & 114 \\
\hline 6.5 & 47 & 82 & 0.50 & 0.17 & 1.2 & 1.0 & 0.13 & 0.08 & 0.003 & 0.023 & 0.037 & 0.017 & 0.018 & 131 \\
\hline $\begin{array}{l}\text { Significance } \\
\mathrm{pH} \times \mathrm{N} \text { form }\end{array}$ & $\begin{array}{l}\mathrm{e} N \mathrm{NS} \\
1\end{array}$ & NS & NS & NS & NS & NS & $*$ & NS & NS & $*$ & NS & NS & NS & NS \\
\hline Significance & e NS & NS & NS & Ns & NS & NS & * & NS & * & NS & NS & NS & NS & NS \\
\hline
\end{tabular}

${ }^{2}$ Mean separation within columns by Duncan's multiple range test, $P<0.05$.

${ }^{y} \mathrm{ND}=$ not detected.

${ }_{N 5 . * * * *}^{*}$ Nonsignificant or significant at $P \leq 0.05$ or 0.01 , respectively. 
nitrate, urea or ammonium nutrition. Plant Physiol. 42:6-14.

Leschyson, M.A. and G.W. Eaton. 1971. Effects of urea and nitrate nitrogen on growth and composition of cranberry vines. J. Amer. Soc. Hort. Sci. 96:597-599.

Lewis, O.A.M., M. Cramer, and T. Van Der Leij. 1990 Influence of nitrogen source on carbon distribution in plants exhibiting the $\mathrm{C} 3$ and $\mathrm{C} 4$ photosynthetic pathways, p. 329-335. In: W.R. Ullrich, C. Rigano, A. Fuggi, and P.J. Aparicio (eds.). Inorganic nitrogen in plants and microorgan- isms: Uptake and metabolism. Springer, Berlin. Marschner, H. 1986. Mineral nutrition of higher plants. Academic, London.

Neuendorff, E.W. and K.D. Patten. 1989. Nitrogen source effect on rabbiteye blueberry leaf organic acid content as determined by HPLC analysis. ASHS 1989 Annu. Mtg., Tulsa, Okla., Prog. \& Abstr. p. 68.

Rosen, C.J., D.L. Allan, and J.J. Luby. 1990. Nitrogen form and solution $\mathrm{pH}$ influence growth and nutrition of two Vaccinium clones. J. Amer. Soc. Hort. Sci. 115:83-89.
SAS Institute. 1985. SAS user's guide: Statistics. Version 5. SAS Inst., Cary, N.C.

Salsac, L., S. Chaillou, J.F. Morot-Gaudry, C. Lesaint, and E. Jolivet. 1987. Nitrate and ammonium nutrition in plants. Plant Physiol. Biochem. 25:805-812.

Woolhouse, H.W. 1966. Comparative physiological studies on Deschampsia flexuosa, Holcus mollis, Arrhenatherum elatius and Koeleria gracilis in relation to growth on calcareous soils. I. Growth and root respiration. New Phytol. 65:22-31. 